\title{
Announcing a new series:
}

\section{Constitutional Thinking}

Jeffrey K. Tulis and Sanford Levinson, series editors

Books in the series will develop constitutional theory beyond legalistic concerns by examining such matters as institutional development; public policy; and political behavior, culture, and theory. The editorial approach, then, favors a constitutional theory embracing the full range of activities relevant to the making, maintenance, and reform of constitutions and constitutional cultures.

\section{Habeas Corpus in America}

\section{The Politics of Individual Rights} Justin J. Wert

By explaining how habeas corpus protections are more contingent than heretofore understood or acknowledged, Wert demonstrates that the Great Writ is a tool of politics and politicians as much as it is a tool of the law and judges. "This is the best history of habeas corpus that I know of," praises Mark Graber. "It both confirms and extends important insights in American constitutional development, as well as providing vital information on a basic constitutional right."

HABEAS CORPUS IN AMERICA The Politics of Individual Rights

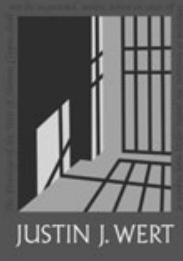
296 pages, Cloth $\$ 34.95$

FORTHCOMING

Family, Change, and the American Constitutional Order Mark E. Brandon
On Constitutional Violence Sanford Levinson

The Civic Constitution John Finn

\section{University Press of Kansas}

Phone 785-864-4155 • Fax 785-864-4586 · www.kansaspress.ku.edu 
CJO Mobile (CJOm) is a streamlined

\section{Cambridge Journals Online (CJO)}

for smartphones and other small mobile devices

- Use CJOm to access all journal content including FirstView articles which are published online ahead of print

- Access quickly and easily thanks to simplified design and low resolution images

- Register for content alerts or save searches and articles they will be available on both CJO and CJOm

- Your device will be detected and automatically directed to CJOm via: journals.cambridge.org 


\section{Political Philosophy}

FROM CHICAGO

Nietzsche's Enlightenment

The Free-Spirit Trilogy of the Middle Period

Paul Franco

"The best book I know of on this period of

Nietzsche's thought."-Michael Allen

Gillespie, Duke University

CLOTH $\$ 40.00$

\section{The Lesson of Carl Schmitt}

Four Chapters on the Distinction between

Political Theology and Political Philosophy.

Expanded Edition

Heinrich Meier

Translated by Marcus Brainard

New Essays Translated by Robert Berman

"Meier's work has forced everyone to take a second look at the assumptions underlying Schmitt's better-known writings."-Mark Lilla, New York Review of Books PAPER $\$ 25.00$

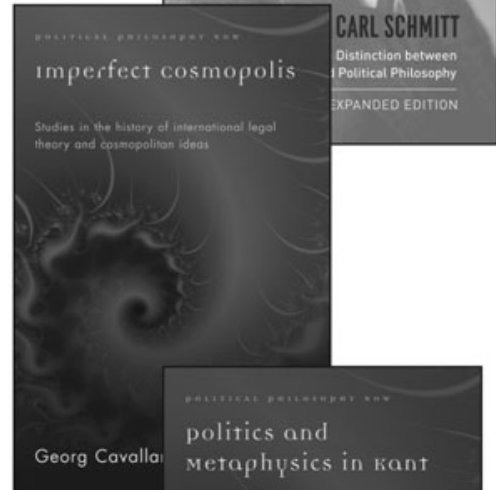

\section{Imperfect Cosmopolis}

\section{FROM THE UNIVERSITY} OF WALES PRESS

Studies in the History of International Legal

Theory and Cosmopolitan Ideas

Georg Cavallar

Imperfect Cosmopolis distinguishes between types of cosmopolitanism and traces the development of the concept through the centuries.

PAPER $\$ 35.00$

\section{Politics and Metaphysics in Kant} Edited by Sorin Baiasu, Sami Pihlström, and Howard Williams

This volume features thirteen cutting-edge essays that explore the relationship between politics and metaphysics in Kant and Kantian political philosophy.

CLOTH $\$ 130.00$

The University of Chicago Press - www.press.uchicago.edu 


\section{CAMBRIDGE}

\section{Outstanding Scholarship from Cambridge}

The Cambridge History of Nineteenth-Century

Political Thought

Edited by Gareth Stedman Jones and Gregory Claeys

The Cambridge History of Political Thought \$195.00: Hb: 978-0-521-43056-2: 1,156 pp.

Political Philosophy in the Twentieth Century

Authors and Arguments

Edited by Catherine Zuckert

\$95.00: Hb: 978-1-107-00622-5: $290 \mathrm{pp}$.

\$29.99: Pb: 978-0-521-18506-6

\section{Political Philosophy} versus History?

Contextualism and Real Politics in Contemporary Political Thought

Edited by Jonathan Floyd and Marc Stears

\$95.00: Hb: 978-0-521-19715-1: 238 pp. \$29.99: Pb: 978-0-521-14688-3
The Cambridge Companion to Nozick's Anarchy, State, and Utopia

Edited by Ralf M. Bader and John Meadowcroft

Cambridge Companions to Philosophy

\$90.00: Hb: 978-0-521-19776-2:332 pp. \$29.99: Pb: 978-0-521-12002-9

\section{Ethics and War}

An Introduction

Steven P. Lee

Cambridge Applied Ethics

\$95.00: Hb: 978-0-521-89883-6:344 pp. \$29.99: Pb: 978-0-521-72757-0

\section{Captives of Sovereignty}

Jonathan Havercroft

\$95.00: Hb: 978-1-107-01287-5: 276 pp.

Symbols of Defeat in the Construction of National Identity

Steven Mock

\$90.00: Hb: 978-1-107-01336-0: 200 pp.

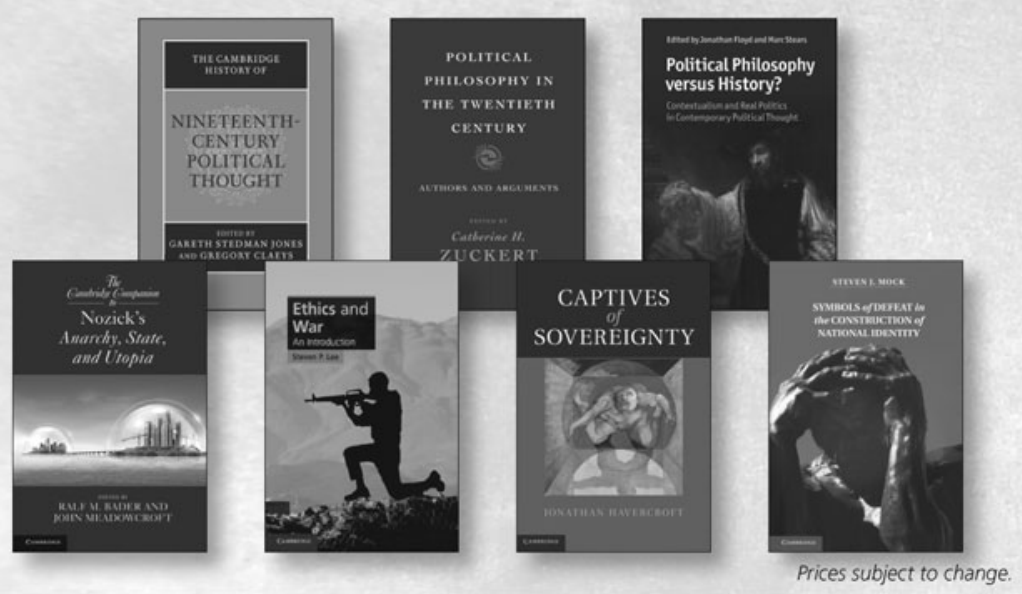




\section{CAMBRIDGE}

\section{Outstanding Scholarship from Cambridge}

International Relations Theory and the Consequences of Unipolarity

Edited by G. John Ikenberry,

Michael Mastanduno, and

William C. Wohlforth

\$95.00: $\mathrm{Hb}$ : 978-1-107-01170-0: $392 \mathrm{pp}$.

\$32.99: Pb: 978-1-107-63459-6

\section{Textbook}

Global Distributive Justice

An Introduction

\section{Chris Armstrong}

\$90.00: Hb: 978-1-107-00892-2:276 pp.

\$32.99: Pb: 978-1-107-40140-2

Global Crises and the

Crisis of Global Leadership

Edited by Stephen Gill

\$95.00: Hb: 978-1-107-01478-7: 316 pp.

\$30.99: Pb: 978-1-107-67496-7

\section{Leaders and International Conflict}

Giacomo Chiozza and H. E. Goemans

\$90.00: Hb: 978-1-107-01172-4: 252 pp.

\$34.99: Pb: 978-1-107-66073-1
Explaining the Iraq War

Counterfactual Theory, Logic and Evidence

Frank P. Harvey

S99.00: Hb: 978-1-107-01472-5: $360 \mathrm{pp}$.

S29.99: Pb: 978-1-107-67658-9

\section{Recovering Liberties}

Indian Thought in the

Age of Liberalism and Empire

C. A. Bayly

Ideas in Context

S85.00: Hb: 978-1-107-01383-4: 404 pp.

S29.99: Pb: 978-1-107-60147-5

\section{Confucianism and \\ Democratization in East Asia}

Doh Chull Shin

\$95.00: Hb: 978-1-107-01733-7: $382 \mathrm{pp.}$ \$28.99: Pb: 978-1-107-63178-6

Models of Economic Liberalization Business, Workers, and Compensation in Latin America, Spain, and Portugal

Sebastián Etchemendy

\$99.00: Hb: 978-0-521-76312-7: $374 \mathrm{pp}$.

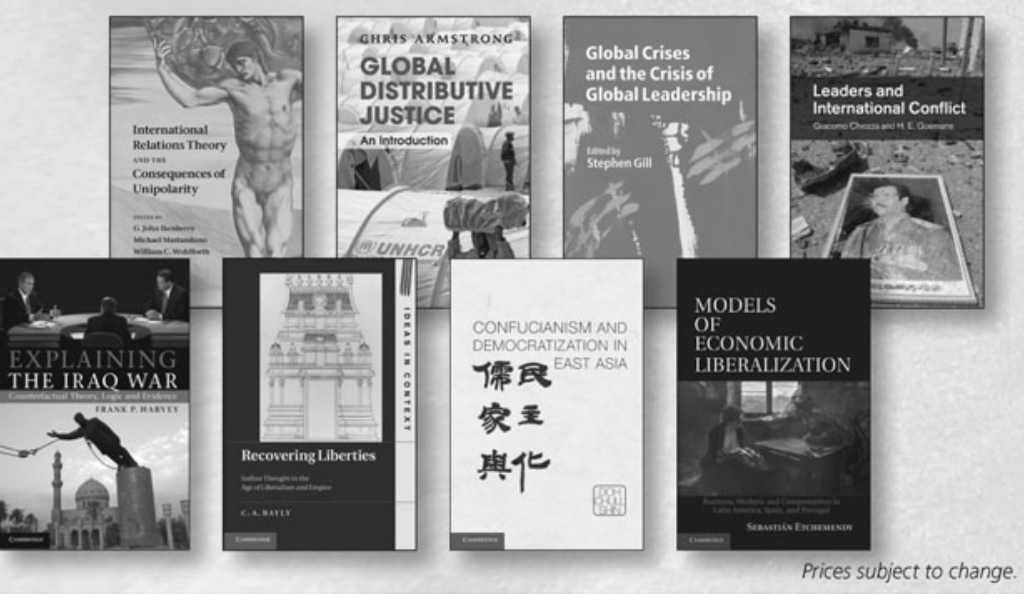


Statement of Ownership, Management, and Circulation (All Periodicals Publications Except Requester Publications)

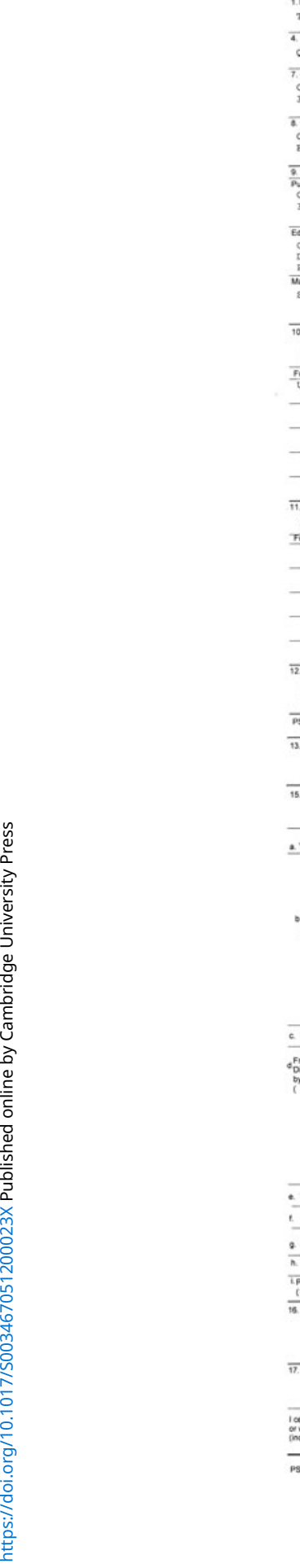

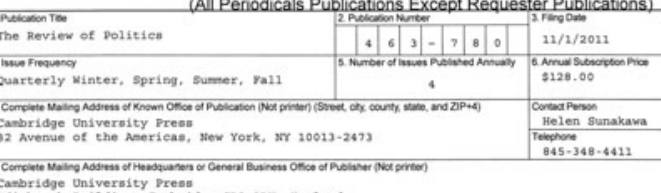

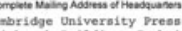

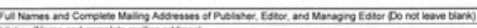

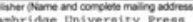

32 Avenue of the Anerieas, New York, sh 20013-2673

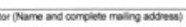

Gatherine zuckert, University of Notre Dase, 947 nanner la11, Notre base, Ist 46556

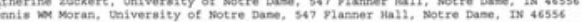

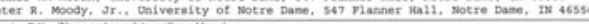

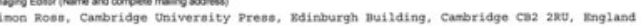

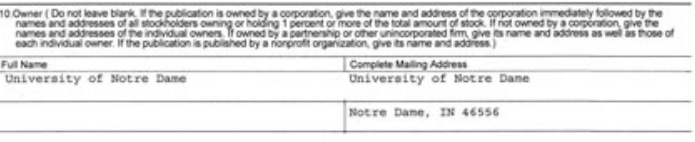

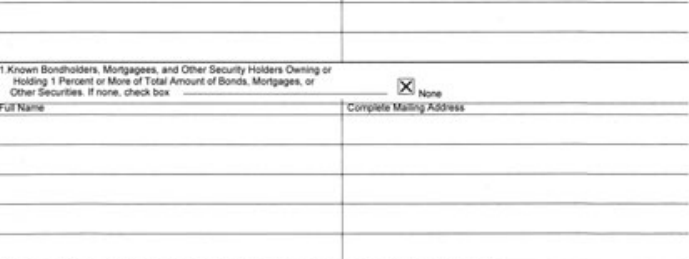

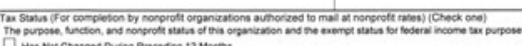

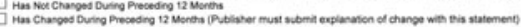

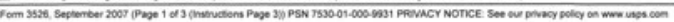

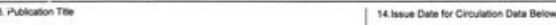

The kevier of politica

\begin{tabular}{|c|c|c|}
\hline Extert and Notiver of Cinculation & 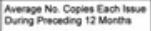 & 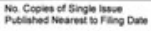 \\
\hline
\end{tabular}

\begin{tabular}{|l|r|r}
\hline Tos Nomber of Copes (Net press run) & 808 & 788 \\
\hline
\end{tabular}

\begin{tabular}{|c|c|c|c|c|}
\hline \multirow{4}{*}{ 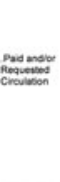 } & (1) & 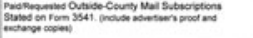 & 341 & 337 \\
\hline & (2) & 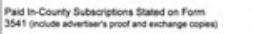 & 0 & 。 \\
\hline & (3) & 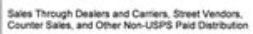 & 136 & 235 \\
\hline & (4) & 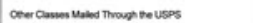 & 。 & 。 \\
\hline \multicolumn{3}{|c|}{ 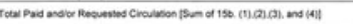 } & 477 & 472 \\
\hline \multirow{4}{*}{ thasen } & (1) & 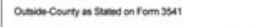 & 76 & 75 \\
\hline & (a) & incovery an stused on form $3 s 41$ & 。 & 。 \\
\hline & (a) & 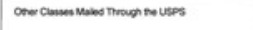 & 。 & $\circ$ \\
\hline & (4) & 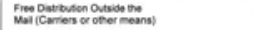 & 69 & 69 \\
\hline \multicolumn{3}{|c|}{ 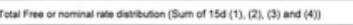 } & 165 & 144 \\
\hline \multicolumn{3}{|c|}{ Tetal Datroveon (Sum of 15e and 15e) } & 622 & 626 \\
\hline \multicolumn{3}{|c|}{ 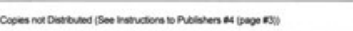 } & 296 & 272 \\
\hline \multicolumn{3}{|c|}{ Total (Sum of 19 and g) } & 800 & 788 \\
\hline \multicolumn{3}{|c|}{ 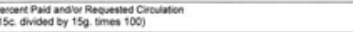 } & $m$ & $m$ \\
\hline
\end{tabular}

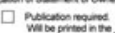

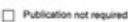

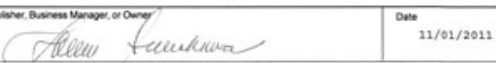

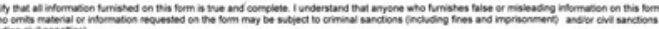

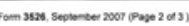




\section{The Review of Politics INSTRUCTIONS TO CONTRIBUTORS}

\begin{abstract}
AIMS AND SCOPE. The Review of Politics publishes primarily philosophical and historical studies of politics, especially those concentrating on political theory and American political thought. The journal also includes thoughtful scholarly reflections on all aspects of politics-including analysis of institutions and techniques, international relations, comparative politics, literary reflections on politics or political interpretations of literary works, constitutional theory and practices.
\end{abstract}

\section{MANUSCRIPT SUBMISSION AND REVIEW.}

To submit a manuscript for consideration please send an electronic file (formatted in MS Word):

\section{THE REVIEW OF POLITICS ONLINE SUBMISSION}

http://mc.manuscriptcentral.com/cup/rop

Complete instructions are provided on the website. The menu will prompt the author to provide all necessary information, including the manuscript category, contact information for the corresponding author (phone number, fax number, email address), and suggested reviewers. The website will automatically acknowledge receipt of the manuscript and provide a reference number. The Editor will assign the manuscript to anonymous reviewers and every effort will be made to provide the author with a review in a timely fashion.

Authors uncomfortable with online submission may send their manuscript as an email attachment to rop.editor.1@nd.edu or two hard copies plus a disk to:

Professor Catherine Zuckert

Editor, The Review of Politics

University of Notre Dame

547 Flanner Hall

Notre Dame, IN 46556

574-631-6623

ROP.Editor.1@nd.edu

www.nd.edu/ rop

BOOK REVIEWS. All correspondence regarding book reviews should be sent to Professor Peter R. Moody, Jr. at the above address.
MANUSCRIPT LENGTH. Normal length of published manuscripts is $8,000-11,000$ words. The entire manuscript, including notes and quotations, should be double-spaced.

Author anonymity. Because manuscripts are evaluated anonymously they should not bear the author's name or institutional affiliation. Please remove all references or acknowledgments that might indicate the identity of the author.

Abstract and keywords. All article submissions should include an abstract of 100-150 words.

\section{MANUSCRIPT PREPARATION AND \\ STYLE. The Review of Politics follows the Chicago Manual of Style for standards of citation, punctuation, and other editorial considerations.}

Figures and tables. Appendices, tables, and figures should be numbered consecutively throughout the article and be included on separate pages appearing after the reference section. Each figure must be submitted electronically as a separate file. Electronic versions should submitted as TIFF or EPS files at $100 \%$ of a suitable final size. Charts, graphs, or other artwork should be professionally rendered and computer generated.

\section{COPYEDITING AND PAGE PROOFS.}

The publisher reserves the right to copyedit and proofread all articles accepted for publication. Page proofs of an article will be sent to the lead author of an article for correction of typographical errors only; authors must notify the publisher or the editorial office of any changes within 72 hours of receipt of proof or approval will be assumed.

COPYRIGHT TRANSFER AGREEMENT. Papers with multiple authors are reviewed with the assumption that all authors concur with its submission. A Copyright Transfer Agreement, with certain specified rights reserved by the author, must be signed and returned to the Editor by senior authors of accepted manuscripts, prior to publication. The Review of Politics does not accept manuscripts for review that are under review elsewhere, previously published, or already committed for publication. 
Aryeh Botwinick, Michael Oakeshott's Skepticism

Gary Jeffrey Jacobsohn, Constitutional Identity

Leigh K. Jenco, Making the Political: Founding and Action in the Political Theory of Zhang Shizhao

Gary L. McDowell, The Language of Law and the Foundations of American Constitutionalism

Susanne Sreedhar, Hobbes on Resistance: Defying the Leviathan Martin J. Sweet, Merely Judgment: Ignoring, Evading, and Trumping the Supreme Court

Wayne Ambler, "Tyranny in Aristophanes"s Birds"

Stanley Brubaker, "John Locke's Theory of Property, God, and Politics"

Susan McWilliams, "Ahab, American"

William Roberts, "All Natural Right Is Changeable: Aristotelian Natural Right, Prudence, and the Specter of Exceptionalism"

Mathew Humphrey and Marc Stears, "Reason-Giving and Political Realism"

Cambridge Journals Online

For further information about this journal please go to the journal website at: journals.cambridge.org/rop 